This document contains an extract from:

Stenström, C. (2014). Operation and maintenance performance of rail infrastructure: Model and methods. PhD thesis. Luleå University of Technology. 



\title{
Performance Indicators of Railway Infrastructure
}

\author{
Authors: \\ C. Stenström, A. Parida and D. Galar
}

Reformatted version of paper originally published in:

International Journal of Railway Technology

Original reference:

C. Stenström, A. Parida, D. Galar, "Performance Indicators of Railway Infrastructure", International Journal of Railway

Technology, 1(3), 1-18, 2012. doi:10.4203/ijrt.1.3.1

http://dx.doi.org/10.4203/ijrt.1.3.1 


\title{
Performance Indicators of Railway Infrastructure
}

\author{
C. Stenström, A. Parida and D. Galar
}

\begin{abstract}
Railway traffic has increased over the last decade and it is believed to increase further with the movement of transportation from road to rail, due to the increasing energy costs and demand to reduce emissions. As a result of increasing need of railway capacity, more efficient and effective operation and maintenance is required. To manage the assets effectively within the business objectives, the results of operation and maintenance activities must be measured and monitored. Performance indicators are developed to support infrastructure managers in decision making, but they are sometimes used ad hoc and and not properly defined. In this paper, performance indicators for railway infrastructure, with primary focus on the railway track, have been mapped and compared with indicators of European Standards. The listed indicators can be applied to form a performance measurement system for railway infrastructure.
\end{abstract}

\section{Introduction}

Railway traffic has increased over the last decade and it is believed to increase further with the movement of transportation from road to rail, due to the increasing energy costs and the demand to reduce emissions. The key goals of the White Paper 2011 for the European transport system include; a $50 \%$ shift of medium distance intercity passenger and freight journeys from road to rail and waterborne transport, and a $60 \%$ cut in transport $\mathrm{CO}_{2}$ emissions by 2050 (EC, 2011). At the same time, the crude oil output reached its all-time peak in 2006 (IEA, 2010). The available capacity of the railways has to be enhanced in order to meet these new demands in transportation.

As railway infrastructure and their components have a long life span, their management requires a long term sustainable strategy. Ongoing technical and economic assessments are necessary to optimise the performance of railway infrastructure and receive the return on investment (ROI) in a manageable timeframe. Long-term asset management objectives and strategies are developed to steer the operation and maintenance activities in the right direction. These objectives need to be broken down into quantitative operation and maintenance objectives to achieve a high level of robustness, punctuality and capacity within the operational budget, at the lowest life cycle cost, with no or an acceptable level of risk. See work by Espling and Kumar (2004), for further discussion on developing maintenance strategies for railway infrastructure.

To manage assets effectively within the agreed objectives, the effect of maintenance activities must be measured and monitored. Performance indicators (PIs) for RAMS (Re- 
liability, availability, maintainability and maintenance supportability), capacity, punctuality, etc., are continuously developed to support infrastructure managers (IMs) to identify performance killers (items that performs poorly or hinders performance) and in making more efficient and effective decisions, but they are sometimes used ad hoc and and not properly defined. Measuring entails data collection, but since raw data does not give any information by itself, these must be analysed, validated and converted to information in the right format for decision making. This consumes resources, especially, if wrong parameters are measured. However, a good performance measurement system does not necessarily require a high level of precision (Kaydos, 1991). It is more important to know whether the trend is up or down and how the current value compares to historical measures. Consistency is therefore especially important in order to capture long term trends, predict future development and take the appropriate corrective actions at an early stage. Thus, if the methods for measuring or analysing are changed, the old information or analysis method should be kept for some time to safeguard the trend tracking. Moreover, performance measurement is also important for feasibility of railway certifications (Faria et al., 2012). It is crucial to thoroughly analyse what to measure, as large costs and equally large savings are associated with measuring. Thus, there exists a need to study the railway PIs used by different IMs, to find out which ones are the most important, which are required and which are not required.

A study was undertaken to review the maintenance PIs used by researchers in the field of railway maintenance, as well as reviewing project reports, policy documents, handbooks, etc. of European IMs. Interviews were also carried out. About 60 managerial maintenance PIs and about 70 infrastructure condition parameters have been identified in the study. Similar indicators have been considered as one in order to limit the total number of indicators.

Increased interoperability and building of a trans-European railway network is another goal of the European Union. The required harmonisation and standardisation of the management of railways have led to increased use of European standards. The identified PIs have therefore been compared to the European Standards; Maintenance Key Performance Indicators (KPIs), EN 15341, in order to find indicators in common (CEN, 2007).

Several projects on indicators and benchmarks for railway transport operations have been carried out, see reviews by EQUIP (2000), IMPROVERAIL (2001) and UTBI (2004). However, similar works on the maintenance aspect are few, which can be seen in Åhrén and Kumar (2004) and Åhrén (2008).

In this study, maintenance performance indicators for railway infrastructure have been mapped and compared with indicators of EN 15341 (CEN, 2007). The listed indicators form a basis for constructing a performance measurement system (PM-system) for railway infrastructure.

This paper is based upon Stenström et al. (2012), but the current paper includes the following additional research: grouping of indicators revised, revised text and figures, besides extended literature review. 


\section{Performance measurement}

Measuring is a management tool which facilitates and supports efficient and effective decision making. In and of itself, it does not determine performance, but it can facilitate good management. What gets measured gets managed is not a promise (Emiliani, 2000).

Organisations use indicators in some form or another to measure their performance. The most common indicators are financial; many of these are mandatory by law. Other indicators are technical, organisational, HSE (health safety and environment), etc. There are few agreements on how to categorise indicators. It is up to each organisation to decide which standards or frameworks to use. Well known standards for maintenance KPIs are the European Standards EN 15341 and SMRP Best practice metrics (CEN, 2007, SMRP, 2011). Use of standardised indicators or metrics, such as the indicators from the standard EN 15341 or the SMRP metrics, has the following advantages (Kahn et al., 2011):

- Maintenance managers can rely on a single set of standardised indicators supported by a glossary of terms and definitions

- The use of standardised indicators makes it easier to compare maintenance and reliability performance across borders

- When a company wants to construct a set of company indicators or scorecard, the development process based on standardised indicators is simplified

- The standardised indicators can be incorporated in various enterprise resource planning (ERP) systems and reports

- The standardised indicators can be adopted and/or modified to fit specific requirements

- The need for discussion and debate on indicator definitions is not required and uncertainties are thus eliminated

Organisations' performance measurement system often grows from the need to measure different processes, thus, the number of databases and indicators grows over time. Some indicators stay while others become obsolete or disappear, but at some point, the amount of information is too large and becomes uncontrollable. The performance measurement system needs to be organised or reorganised, databases and indicators must be documented, regulations set, gaps must be identified, the performance measurement system must be aligned to the business goals and the owners of databases and indicators must be clear. See Figure 1, for high level requirements (HLRs) for organising a measurement system. Supportive guidelines for asset management in railways can be found in a work by International Union of Railways (UIC, 2010), as a seven-step procedure based on the following standards and manuals: PAS 55, the asset management standard by British Standards Institute (BSI, 2008a,b); the International Infrastructure Management Manual (IIMM) by New Zealand Asset Management Steering (NAMS) Group (INGENIUM 


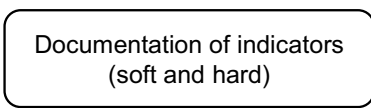

- Indicators in use

- Defining indicators

- Indicators for benchmarking

- Defining scorecards

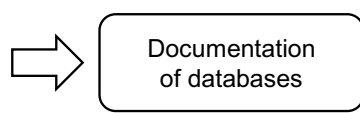

- Defining databases

- Quality of data

- Usability

\section{Setting up}

regulations

- Usage of databases and indicators

- Registration of indicator

- Ownership

Figure 1: High level requirements for organising or reorganising a performance measurement system (PM-system).

and NAMS, 2006); and the Asset Management Overview by the US Highway Agency (FHWA, 2007).

According to Gillet, Woodhouse found that a human cannot control and monitor more than four to eight indicators at the same time (Gillett, 2001). Data aggregation is therefore necessary (Parida and Chattopadhyay, 2007); see Figure 2. As an example in railways, capacity and availability goals can be broken down to system and component performance requirements at the infrastructure level. The result is then aggregated and compared to the set objectives by use of indicators.

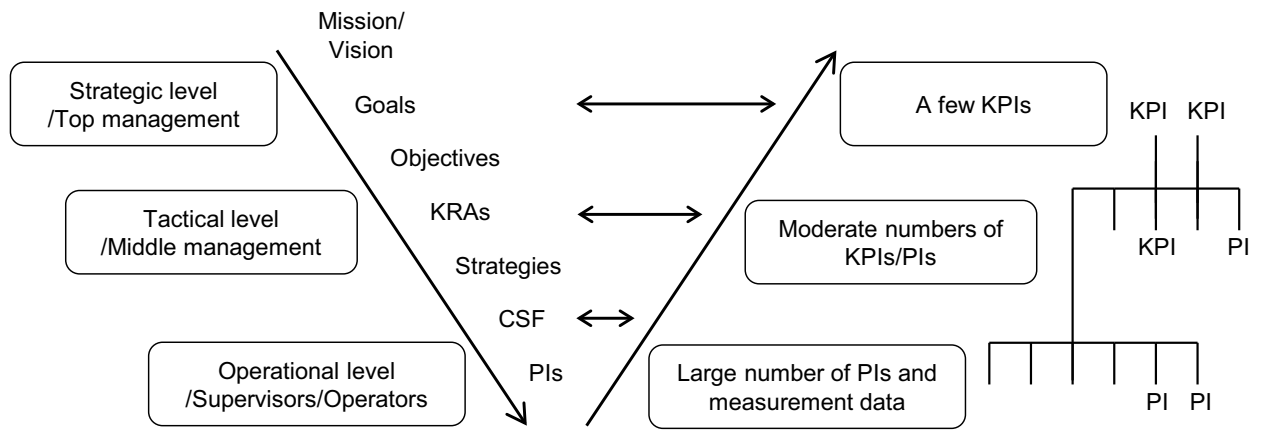

$\mathrm{KRA}=$ key result area; where the result and indicators are visualised

$\mathrm{CSF}=$ critical success factor; to succeed with set objectives

$\mathrm{KPI}=$ Key performance indicator $(\mathrm{PI})$

Figure 2: Breakdown of goals and objectives and aggregation of data.

It is not possible to measure everything with only quantitative or only qualitative methods. Rather a combination of both methods must be used to create a measurement system that is as complete as possible. Qualitative measurement methods are good for measuring soft values like employee satisfaction and for checking conformity with 
quantitative indicators. Galar et al. (2010, 2011) have merged qualitative measures with quantitative ones and developed an audit that shows the relation between trends in questionnaires and indicators, validating the correlation or highlighting the divergence.

As this paper focuses on quantitative indicators, there are few qualitative indicators which are presented.

\subsection{Railway infrastructure performance indicators}

A study was undertaken to review the railway infrastructure PIs used by researchers and professionals in the field of railway infrastructure, as well as reviewing project reports, policy documents, handbooks, etc., of European IMs. Interviews of the Swedish IM were also carried out. In order to manage the large number of indicators, they have been grouped into two overall groups; managerial and infrastructure condition indicators. The managerial indicators are extracted from different computer systems, e.g. enterprise resource planning (ERP), computerised maintenance management system (CMMS), etc., excluding condition monitoring data. Condition monitoring indicators are all the indicators and parameters extracted by sensors and by various inspection methods in the railway network. Managerial indicators are more at an overall system level compared to condition monitoring data that are at a subsystem or component level. See work by Stenström et al. (2011) for further discussion on terminology of performance indicators.

The PIs of EN 15341 are grouped into three categories; economic, technical and organisational. Health, safety and environment (HSE) indicators are part of the technical indicators. The railway managerial indicators are grouped accordingly, but the HSE indicators have been considered to have such importance that they have been put into a separate group. Condition monitoring data have been divided into six groups, see Figure 3. The groups can also be called key result areas; the few areas where the result and indicators are visualised (Leidecker and Bruno, 1984).

The following subsections present the four groups of managerial indicators and the six groups of the condition monitoring indicators.

\section{Managerial indicators}

The managerial indicators are put into system and subsystem levels. System is considered as the whole railway network supervised by an IM. Subsystems are railway lines, classes, specific assets and items. Some indicators are found at both levels, while others are only found at one level. Each indicator has been given an identification number (\#) similar to the system used in EN 15341 (CEN, 2007), i.e. starting with E, T, O, and for the fourth group, it starts with $\mathrm{H}$.

Technical indicators are closely related to reliability, availability and maintainability (RAM); see Tables A.1 and A.2. The research is extensive: for work on failure frequencies and delays, see Nyström and Kumar (2003), Granström and Söderholm (2005), Granström (2008) and VTI (2011); for maintainability, see Nyström and Kumar (2003) and INNOTRACK (2009); for capacity, see UIC (2004) and Åhrén and Kumar (2004); 


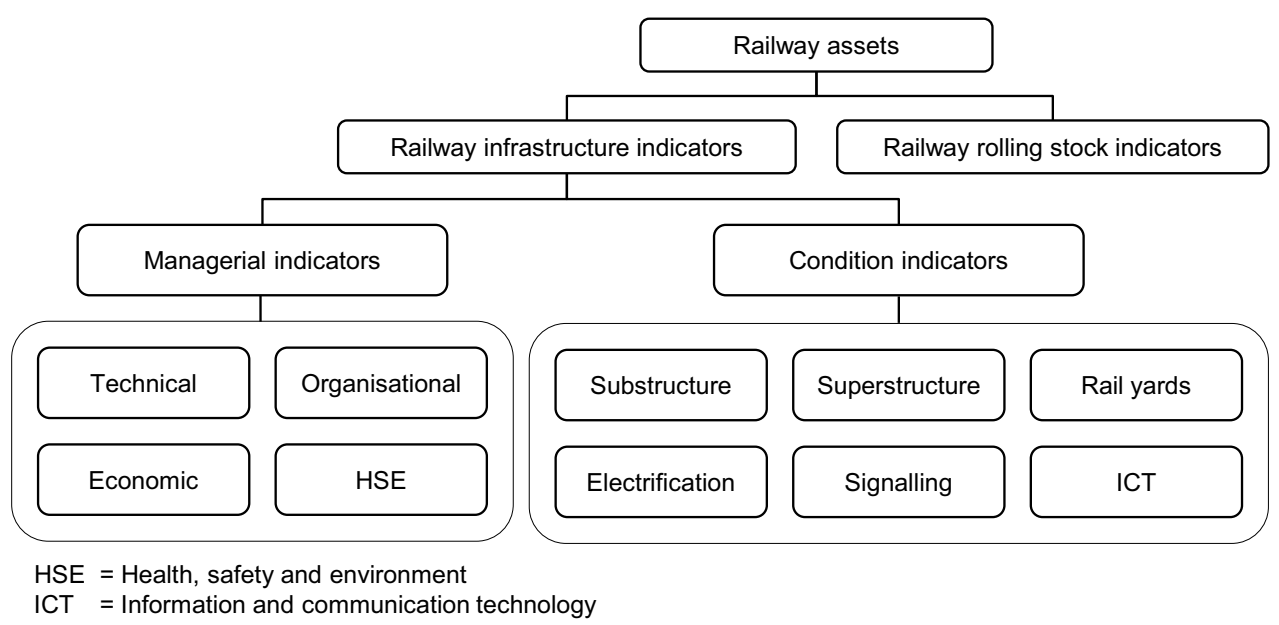

Figure 3: Structure of railway infrastructure performance indicators.

and for overall equipment effectiveness (OEE) and data envelopment analysis (DEA), see George and Rangaraj (2008), Åhrén and Parida (2009) and Malhotra et al. (2009).

Quantitative indicators should always be complemented with qualitative indicators, like questionnaires. This has special importance in the organisational perspective due to strong human interactions. See Table A.3, for quantitative organisational indicators.

Many overall financial indicators are regulated by the ministry of the IM and are therefore easy to find; see Table A.4. Besides annual reports, those indicators are also often used in high-level benchmarking, e.g. see Parida and Chattopadhyay (2007) and Galar et al. (2010). Similar cost indicators at operational level, i.e. per item, are scarcer, but research is carried out, e.g. on switches and crossings by REMAIN (1998), Nissen (2009a) and Nissen (2009b).

Maintenance staffs are exposed to hazards and suffer from bad ergonomics due to unstandardized or non-routine work, lowered barriers, leakage, pressure, electricity, etc. (Galar et al., 2011). As in all forms of rail transportation, the safety is a critical factor. Thus, HSE has a special importance in the management of railway infrastructure maintenance. General HSE indicators are easy to find and often required by law, but specific ones for maintenance are scarcer. Both types have been considered in Table A.5.

\section{Condition monitoring indicators}

The railway condition monitoring (CdM) indicators have been divided into six groups; substructure, superstructure, rail yards, electrification, signalling, and information and communication technology (ICT), Figure 3. Condition monitoring of these assets has been mapped by studying various inspection methods, mainly from Esveld (2001), INNOTRACK (2008) and BSL (2009); see Tables A.6 and A.7. Ocular inspections and 
manual inspections using gauges have been left out due to their large number of routines. Bridges and tunnels condition monitoring have not been considered either; they are out of the scope of this paper. Wayside detectors are monitoring trains; only the infrastructure is considered in this paper. Nevertheless, the rolling stock is as important as the infrastructure since it will be in similar condition (Lardner, 1850). See work by Bracciali (2012) for a state-of-the-art review on wayside detectors.

\subsection{Constructing a railway maintenance scorecard}

A scorecard, scorebook or scoresheet in business is a statistical record used to measure achievement or progress towards a particular goal (Oxford Dict., 2011).

For a successful MPM-system, it needs to be able to provide the right information at the right time, to the right people, in the right quantity and format (Parida and Kumar, 2004). According to Gillett (2001), Woodhouse found that a human cannot control and monitor more than four to eight indicators at the same time. For these reasons, it is essential to find the right indicators for the different organisational levels, indicators that match the objectives and strategy of the business. With use of a scorecard the top management can oversee the indicators for each responsibility, e.g. operations, financial, HR, etc. The indicators and parameters in Tables A.1-7 have been brought together into a scorecard; see Table 1.

Table 1: Railway infrastructure performance measurement scorecard.

\begin{tabular}{|c|c|c|c|}
\hline Perspective & Aspect & \multicolumn{2}{|c|}{ Indicators [no.] } \\
\hline & Managerial & System & Subsystem \\
\hline \multirow{6}{*}{ Technical } & Availability & 7 & 7 \\
\hline & Maintainability & 1 & 1 \\
\hline & Capacity consumption & 1 & 3 \\
\hline & Riding comfort & - & 1 \\
\hline & OEE and DEA & - & 2 \\
\hline & Age & - & 1 \\
\hline \multirow{2}{*}{ Organisational } & Maintenance management & 4 & 2 \\
\hline & Failure reporting process & 1 & 1 \\
\hline Economic & Allocation of cost & 6 & 1 \\
\hline \multirow{4}{*}{ HSE } & Health & 3 & - \\
\hline & Safety - General & 6 & - \\
\hline & Safety - Maintenance & 4 & - \\
\hline & Environment & 4 & - \\
\hline \multicolumn{2}{|c|}{ Condition monitoring } & Subsystem & Component \\
\hline \multirow{6}{*}{ Technical } & Substructure & 6 & 16 \\
\hline & Superstructure & 10 & 30 \\
\hline & Rail yard & - & - \\
\hline & Electrification & - & - \\
\hline & Signalling & 1 & 4 \\
\hline & $\begin{array}{l}\text { Information communication } \\
\text { tech. }\end{array}$ & - & - \\
\hline
\end{tabular}




\section{Linking railway indicators to EN 15341}

The indicators of EN 15341 consist of 71 key performance indicators (KPIs) categorised into three groups and three levels (CEN, 2007). The groups are economic, technical and organisational indicators, and the levels are going from general indicators to more specific indicators. The KPIs have been constructed by taking the ratio of two or more factors, or PIs. The railway indicators have therefore been compared both with the factors and the KPIs of level one to three; see Tables 2 and 3. Indicators at the same row are considered to be closely related to each other.

Table 2: Relationship between railway PIs and EN 15341 PIs.

\begin{tabular}{|c|c|c|c|}
\hline \multicolumn{2}{|r|}{ Railway PIs } & \multicolumn{2}{|r|}{ EN 15341 PIs } \\
\hline \# & Name/Description & $\#$ & Name/Description \\
\hline $\begin{array}{l}\mathrm{E} 3= \\
\mathrm{E} 1 / \mathrm{T} 17\end{array}$ & $\begin{array}{l}\text { Maintenance cost / Traffic } \\
\text { volume }\end{array}$ & E3 & $\begin{array}{l}\text { Total maintenance cost / Quan- } \\
\text { tity of output }\end{array}$ \\
\hline $\mathrm{E} 2 / \mathrm{E} 1$ & $\begin{array}{l}\text { Maintenance management cost } \\
\text { / Maintenance cost }\end{array}$ & E13 & $\begin{array}{l}\text { Cost for indirect maintenance } \\
\text { personnel / Total maintenance } \\
\text { cost }\end{array}$ \\
\hline $\mathrm{E} 4 / \mathrm{E} 1$ & $\begin{array}{l}\text { Maintenance contractor cost / } \\
\text { Maint. cost }\end{array}$ & E10 & $\begin{array}{l}\text { Total contractor cost / Total } \\
\text { maintenance cost }\end{array}$ \\
\hline E1/H15 & $\begin{array}{l}\text { Maintenance cost / Energy } \\
\text { consumption per area }\end{array}$ & E14 & $\begin{array}{l}\text { Total maintenance cost / Total } \\
\text { energy used }\end{array}$ \\
\hline $\mathrm{E} 5 / \mathrm{E} 1$ & $\begin{array}{l}\text { Corrective maintenance cost / } \\
\text { Maintenance cost }\end{array}$ & E15 & $\begin{array}{l}\text { Corrective maintenance cost / } \\
\text { Total maintenance cost }\end{array}$ \\
\hline $\mathrm{E} 6 / \mathrm{E} 1$ & $\begin{array}{l}\text { Preventive maintenance cost / } \\
\text { Maint cost }\end{array}$ & E16 & $\begin{array}{l}\text { Preventive maint. cost / Total } \\
\text { maint. cost }\end{array}$ \\
\hline $\begin{array}{l}\text { H10/ } \\
\text { Time }\end{array}$ & $\begin{array}{l}\text { Maintenance accidents and } \\
\text { incidents / Time }\end{array}$ & $\mathrm{T} 5$ & $\begin{array}{l}\text { Injuries for people due to main- } \\
\text { tenance / Working time }\end{array}$ \\
\hline \multirow[t]{2}{*}{$\mathrm{H} 11 / \mathrm{T} 3$} & \multirow[t]{2}{*}{$\begin{array}{l}\text { Failure accidents and incidents } \\
\text { / Failures in total }\end{array}$} & $\mathrm{T} 11$ & $\begin{array}{l}\text { Failures causing injury to peo- } \\
\text { ple / Number of failures }\end{array}$ \\
\hline & & $\mathrm{T} 12$ & $\begin{array}{l}\text { Failures causing pot. injury to } \\
\text { people / Number of failures }\end{array}$ \\
\hline $\mathrm{O} 2+\mathrm{T} 16$ & $\begin{array}{l}\text { Mean waiting time }(\mathrm{MWT})+ \\
\text { Mean time to repair }(\mathrm{MTTR})\end{array}$ & $\mathrm{T} 21$ & $\begin{array}{l}\text { Total time to restoration / } \\
\text { Number of failures }\end{array}$ \\
\hline O3 & Maintenance backlog & $\mathrm{O} 22$ & $\begin{array}{l}\text { Work orders performed as } \\
\text { scheduled / Scheduled work } \\
\text { orders }\end{array}$ \\
\hline
\end{tabular}


Table 3: Relationship between railway PIs and EN 15341 PIs.

\begin{tabular}{|l|l|l|l|}
\hline \multicolumn{2}{|c|}{ Railway PIs } & \multicolumn{2}{c|}{ EN 15341 PIs } \\
\hline$\#$ & Name/Description & $\#$ & Name/Description \\
\hline E1 & Maintenance cost & E1.1 & Total maintenance cost \\
\hline T17 & Traffic volume & E3.2 & Quantity of output \\
\hline E2 & Maintenance management cost & E13.1 & $\begin{array}{l}\text { Cost for indirect maintenance } \\
\text { personnel }\end{array}$ \\
\hline E4 & Maintenance contractor cost & E10.1 & Total contractor cost \\
\hline H15 & Energy consumption per area & E14.2 & Total energy used \\
\hline E5 & Corrective maintenance cost & E15.1 & Corrective maintenance cost \\
\hline E6 & Preventive maintenance cost & E16.1 & Preventive maintenance cost \\
\hline H10 & $\begin{array}{l}\text { Maintenance accidents and } \\
\text { incidents }\end{array}$ & T5.1 & $\begin{array}{l}\text { Injuries for people due to mainte- } \\
\text { nance }\end{array}$ \\
\hline T3 & Failures in total & T11.2 & Total number of failures \\
\hline \multirow{2}{*}{ H11 } & Failure accidents and incidents & T11.1 & Failures causing injury to people \\
\cline { 2 - 4 } & & T12.1 & $\begin{array}{l}\text { Failures causing pot. injury to } \\
\text { people }\end{array}$ \\
\hline
\end{tabular}

\section{Discussion}

Maintenance performance indicators for railway infrastructure have been identified and listed in Tables A.1-7. Similar indicators have been considered as one indicator. Some indicators have been added, since they are considered as general indicators, e.g. maintenance personnel absenteeism. The listed indicators form a basis for constructing a performance measurement system for railway infrastructure. Though, the focus has been on the railway track, besides considering some parts of the overhead contact system, other systems have not been considered, e.g. bridges, tunnels, and signalling. Moreover, studies have shown that the railway infrastructure and train operating companies (TOCs) are responsible for 20-30\% and 30-40\% of the train delay, respectively (Espling and Kumar, 2004, Nyström and Kumar, 2003, Granström and Söderholm, 2005). The studies also showed that the rolling stock, vehicle failures, is responsible for 10-20\% of the delay. Performance measurement and indicators for assessing the performance of rolling stock and operations are therefore likewise important for the credibility and dependability of railways. Extensive work on indicators and benchmarking on this have been carried out in (EQUIP, 2000, IMPROVERAIL, 2001, Adeney, 2003, Anderson et al., 2003, UTBI, 2004).

The identified indicators have been compared to EN 15341 (CEN, 2007) in Tables 2 and 3. It was found that 11 PIs are similar. A number of the indicators in the European standard are general for any maintenance functions. Nevertheless, it has to be kept in mind that the standard is mainly for manufacturing businesses and not for linear assets. Thus, many railway indicators cannot be found in the standard.

The scorecard in Table 1 has two groups called availability and capacity, respectively. 
Availability related indicators are considered as indicators of punctuality, regularity, failures, delay and temporary speed restrictions, while capacity related indicators are of traffic volume and capacity consumption. The latter one is according to UIC (2004). However, any general availability indicators for railways could not be found, such as uptime measures, or like indicator T1 of EN 15341: Total operating time / Total Operating time + Downtime due to maintenance. Regarding capacity, the indicator Capacity consumption by UIC (2004) is extensively used by IMs, which is a measure of how occupied an infrastructure is. Thus, the amount of output, effective capacity, or such, is not measured.

Performance measurement of railway infrastructure provides information regarding the condition of systems and components. Failure rates, failure causes and the corresponding delays can be monitored and compared to expected lifetime calculations. Thus, it provides additional inputs to lifecycle costing and cost-benefit analysis, which can be made more accurate. However, it requires a well-developed performance measurement system with consistency over time for trend tracking. For a thorough review of railway maintenance cost estimation, see work by Ling (2005).

\section{Conclusions}

A study of the performance measurement of railway infrastructure was undertaken. As a result, performance indicators of railway infrastructure have been listed in Tables A.1-7 and categorised into two groups; managerial and condition monitoring indicators. The identified indicators have been compared to EN 15341 (CEN, 2007); 11 indicators were found to be similar, which can facilitate external benchmarking.

Infrastructure managers use performance measurement to study whether results are in line with set objectives, for predicting maintenance and reinvestments, decision support and benchmarking, i.e. business safety. The listed indicators can therefore be used by infrastructure managers for reviewing and improving their performance measurement system. It also provides a background for a possible future standardisation of railway indicators. However, harmonising between infrastructure managers for benchmarking is a challenge, since the operational and geographical conditions varies extensively.

This study has been mainly focused on the railway track. Scope of future work can be on other infrastructure assets and the rolling stock.

\section{Acknowledgements}

The authors would gratefully acknowledge the research grant provided by Trafikverket (TRV), the Swedish Transport Administration, for conducting the study in this paper. Especially, the authors would like to thank Vivianne Karlsson and Per Norrbin and at TRV for valuable discussions and advice. The authors would also like to thank Ulla Juntti, Uday Kumar and Stephen Famurewa, Luleå University of Technology (LTU), as well as Per-Olof Larsson-Kråik, TRV and LTU, for assistance and advice. 


\section{References}

Åhrén, T. and Kumar, U. (2004). Use of maintenance performance indicators: A case study at Banverket. In Nezamirad, K., Higgins, P. G., and Dunstall, S., editors, Conference proceedings of the $5^{\text {th }}$ Asia-Pacific Industrial Engineering and Management Systems Conference (APIEMS2004), pages 30.8.1-30.8.9.

Adeney, W. (2003). Metro benchmarking: CoMET and Nova deliver tangible benefits. Railway Gazette; Metro report, 159:15-18.

Åhrén, T. (2008). Maintenance Performance Indicators (MPIs) for Railway Infrastructure: Identification and Analysis for Improvement. PhD thesis, Luleå University of Technology.

Åhrén, T. and Parida, A. (2009). Overall railway infrastructure effectiveness (ORIE): A case study on the Swedish rail network. Journal of Quality in Maintenance Engineering, 15(1):17-30.

Anderson, R., Hirsch, R., Trompet, M., and Adeney, W. (2003). Developing benchmarking methodologies for railway infrastructure management companies. In Proceedings of the European Transport Conference 2003. Association for European Transport (AET).

Banverket (2003). Framtidsplan för järnvägen: Infrastruktursatsningar nationellt 20042015. Technical report, Banverket.

Banverket (2007). BVH 800: Vägledning till banverkets underhållsstrategi.

Banverket (2010). Annual report 2009. Technical report, Banverket.

Bracciali, A. (2012). Wayside train monitoring systems: A state-of-the-art and running safety implications. International Journal of Railway Technology, 1(1):231-247.

BSI (2008a). PAS 55-1: Asset management, Part 1: Specification for the optimized management of physical assets. Technical report, British Standards Institution (BSI).

BSI (2008b). PAS 55-2: Asset management, Part 2: Guidelines for the application of PAS 55-1. Technical report, British Standards Institution (BSI).

BSL (2009). Asset management club project. Technical report, BSL Management Consultants.

CEN (1999). EN 50126: Railway specifications - The specification and demonstration of reliability, availability, maintainability and safety (RAMS). Technical report, European Committee for Standardization (CEN).

CEN (2007). EN 15341: Maintenance: Maintenance key performance indicators. Technical report, European Committee for Standardization (CEN). 
EC (2011). White paper: Roadmap to a single European transport area: Towards a competitive and resource efficient transport system. European Commission (EC).

Emiliani, M. L. (2000). The false promise of what gets measured gets managed. Management Decision, 38(9):612-615.

EQUIP (2000). Extending the quality of public transport: Final report. Technical Report UR-98-RS.3076, TRKC (Transport Research Knowledge Centre).

Espling, U. and Kumar, U. (2004). Development of a proactive maintenance strategy for railway infrastructure; a case study. In Workshop Proceedings of the International Maintenance Congress Euromaintenance, pages 31-38.

Esveld, C. (2001). Modern railway track. MRT-Productions, Netherlands, $2^{\text {nd }}$ edition.

Famurewa, S. M., Juntti, U., and Kumar, U. (2011). Performance based railway infrastructure maintenance: Towards achieving maintenance objectives. In Galar, D., Parida, A., Schunnesson, H., and Kumar, U., editors, $1^{\text {st }}$ International Conference on Maintenance Performance Measurement and Management (MPMM), pages 233-240. LuleåUniversity of Technology.

Faria, J., Almeida, J., Cordeiro, R., Rodrigues, J., and Barbosa, R. (2012). Railway certification: Reliability, availability, maintainability and safety calculations. In Pombo, J., editor, Proceedings of the First International Conference on Railway Technology: Research, Development and Maintenance. Civil-Comp Press, Stirlingshire, UK.

FHWA (2007). Asset management overview. U.S. Department of Transportation, Federal Highway Administration, Washington, DC.

Galar, D., Berges, L., and Royo, J. (2010). La problemática de la medición del rendimiento en la función mantenimiento (The issue of performnance measurement in the maintenance function). Ataque Frontal al Visado Industrial, 85,.

Galar, D., Stenström, C., Parida, A., Kumar, R., and Berges, L. (2011). Human factor in maintenance performance measurement. In Industrial Engineering and Engineering Management (IEEM), 2011 IEEE International Conference on, pages 1569-1576.

George, S. A. and Rangaraj, N. (2008). A performance benchmarking study of indian railway zones. Benchmarking: An International Journal, 15(5):599-617.

Gillett, K. (2001). Measuring maintenance performance: A structured approach.

Granström, R. (2008). A system and stakeholder approach for the identification of condition information: a case study for the Swedish railway. Proceedings of the Institution of Mechanical Engineers, Part F: Journal of Rail and Rapid Transit, 222(4):399-412. 
Granström, R. and Söderholm, P. (2005). Punctuality measurements effect on the maintenance process: a study of train delay statistics for the Swedish railway. In Proceedings of the $8^{\text {th }}$ international conference and exhibition of Railway Engineering, London, UK.

Holmgren, M. (2005). Maintenance-related losses at the swedish rail. Journal of Quality in Maintenance Engineering, 11(1):5-18.

IEA (2010). World energy outlook 2010. International Energy Agency (IEA), Paris, France.

IMPROVERAIL (2001). Improved tools for railway capacity and access management: D2 benchmarking methodologies and harmonisation of concepts in the railway sector. Technical report, Competitive and Sustainable Growth Programme.

INGENIUM and NAMS (2006). International infrastructure management manual (IIMM). Association of Local Government Engineering NZ Inc. (INGENIUM), National Asset Management Steering (NAMS) Group, Thames, N.Z, $3^{\text {rd }}$ edition.

INNOTRACK (2008). D4.4.1: Rail inspection technologies. Technical report, International Union of Railways (UIC).

INNOTRACK (2009). D6.4.1: Key values for LCC and RAMS. Technical report, International Union of Railways (UIC).

Kahn, J., Svantesson, T., Olver, D., and Poling, A. (2011). Global maintenance and reliability indicators: Fitting the pieces together, volume $4^{\text {th }}$. EFNMS (European Federation of National Maintenance Societies) and SMRP (Society for Maintenance \& Reliability Professionals), Brussels, $4^{\text {th }}$ edition.

Kaydos, W. (1991). Measuring, managing and maximizing performance. Productivity Press, Portland, $1^{\text {st }}$ edition.

Lardner, D. (1850). Railway economy. Taylor, Walton and Mabe, London.

Leidecker, J. K. and Bruno, A. V. (1984). Identifying and using critical success factors. Long range planning, 17(1):23-32.

Ling, D. (2005). Railway renewal and maintenance cost estimating. PhD thesis, Cranfield University.

Malhotra, R., Malhotra, D. K., and Lermack, H. (2009). Using data envelopment analysis to analyze the performance of North American class I freight railroads, pages 113-131. Financial Modeling Applications and Data Envelopment Applications: Applications of Management Science, Volume 13. Emerald.

Nissen, A. (2009a). Classification and cost analysis of switches and crossings for the Swedish railway: A case study. Journal of Quality in Maintenance Engineering, 15(2):202-220. 
Nissen, A. (2009b). LCC for switches and crossings at the Swedish railway: A case study. International Journal of Condition Monitoring and Diagnostic Engineering Management COMADEM, 12(2):10-19.

Nyström, B. and Kumar, U. (2003). Analysis of train delay information. In Proceedings of the World Congress on Railway Research (WCRR), pages 253-261.

Olsson, U. and Espling, U. (2004). Part I: A framework for partnering for infrastructure maintenance. Journal of Quality in Maintenance Engineering, 10(4):234-247.

Oxford Dict. (2011). Oxford English dictionary online.

Parida, A. and Chattopadhyay, G. (2007). Development of a multi-criteria hierarchical framework for maintenance performance measurement (MPM). Journal of Quality in Maintenance Engineering, 13(3):241-258.

Parida, A. and Kumar, U. (2004). Managing information is the key to maintenance effectiveness. In Proceedings of the IMS 2004 International Conference on Intelligent Maintenance Systems.

REMAIN (1998). Modular system for reliability and maintainability management in european rail transport: Life cycle cost analysis in railway systems. Technical Report STF38 A98424, SINTEF Industrial Management.

SMRP (2011). SMRP best practice metrics 2011. Technical report, Society for Maintenance \& Reliability Professionals (SMRP).

Söderholm, P. and Norrbin, P. (2011). A risk-based dependability approach to link maintenance performance measurement and management to overall objectives: A case study within the Swedish railway. In Galar, D., Parida, A., Schunnesson, H., and Kumar, U., editors, $1^{\text {st }}$ International Conference on Maintenance Performance Measurement and Management (MPMM), pages 241-247. Luleå University of Technology.

Stenström, C. (2012a). Maintenance performance measurement of railway infrastructure with focus on the Swedish network. Technical report, Luleå University of Technology.

Stenström, C. (2012b). Link and effect model for performance improvement of railway infrastructure. Licentiate thesis, Luleå University of Technology.

Stenström, C., Parida, A., and Galar, D. (2012). Maintenance performance indicators for railway infrastructure management. In Pombo, J., editor, Proceedings of the First International Conference on Railway Technology: Research, Development and Maintenance. Civil-Comp Press, Stirlingshire, UK.

Stenström, C., Parida, A., Kumar, U., and Galar, D. (2011). Maintenance value drivers, killers and their indicators. In Galar, D., Parida, A., Schunnesson, H., and Kumar, U., editors, $1^{\text {st }}$ International Conference on Maintenance Performance Measurement and Management (MPMM), pages 125-130. Luleå University of Technology. 
Trafikverket (2011). Annual report 2010. Technical report, Trafikverket.

UIC (2004). Leaflet 406: Capacity. Technical report, International Union of Railways (UIC).

UIC (2010). Guidelines for the application of asset management in railway infrastructure organisations. Technical report, International Union of Railways (UIC).

UIC - LICB (2008). Lasting infrastructure cost benchmarking (LICB): Summary report. Technical report, International Union of Railways (UIC).

Unckel, P. (2010). Förbättrad vinterberedskap inom järnvägen. Technical Report SOU 2010:69, Elanders Sverige AB.

UTBI (2004). The urban transport benchmarking initiative: Year one final report. Technical report, Transport Research Knowledge Centre (TRKC).

VTI (2011). A strategy for developing a framework for economic analysis of operation, maintenance and renewal of road and rail infrastructures. Technical Report 92391, VTI, Statens väg- och transportforskningsinstitut.

Wireman, T. (2003). Benchmarking best practices in maintenance management. Industrial Press Inc., New York, $2^{\text {nd }}$ edition. 


\section{A Tables}

Table A.1: Technical railway infrastructure indicators.

\begin{tabular}{|c|c|c|c|}
\hline \multicolumn{4}{|c|}{ Technical indicators } \\
\hline Category & Indicators (Comments) [Unit] & Reference & \# \\
\hline \multirow{16}{*}{ Availability } & \multicolumn{3}{|l|}{ System level } \\
\hline & $\begin{array}{l}\text { Arrival punctuality [no. or } \% \text {, passenger or } \\
\text { freight] }\end{array}$ & $\begin{array}{l}\text { (Banverket, 2010, } \\
\text { Söderholm and Norrbin, } \\
\text { 2011) }\end{array}$ & $\mathrm{T} 1$ \\
\hline & $\begin{array}{l}\text { Train regularity [no. or } \% \text {, passenger or } \\
\text { freight] }\end{array}$ & (Banverket, 2010) & $\mathrm{T} 2$ \\
\hline & Failures in total [no.] & \multirow{3}{*}{$\begin{array}{l}\text { (Nyström and Ku- } \\
\text { mar, 2003, Granström } \\
\text { and Söderholm, 2005, } \\
\text { Granström, 2008, VTI, } \\
\text { 2011, CEN, 1999, Ban- } \\
\text { verket, 2003) }\end{array}$} & T3 \\
\hline & Train delay [time] & & $\mathrm{T} 4$ \\
\hline & $\begin{array}{l}\text { Delay per owner (Operation centrals, Sec- } \\
\text { ondary delays, Infrastructure, Train opera- } \\
\text { tors, Accidents and incidents, etc.) [\%/owner] }\end{array}$ & & $\mathrm{T} 5$ \\
\hline & Faults interfering with traffic [no. or \%] & (Banverket, 2007) & $\mathrm{T} 6$ \\
\hline & Temporary speed restrictions (TSRs) [no.] & (BSL, 2009) & $\mathrm{T} 7$ \\
\hline & \multicolumn{3}{|l|}{ Subsystem level } \\
\hline & $\begin{array}{l}\text { Punctuality per line, line class or area [no. or } \\
\% / \text { line, class or area] }\end{array}$ & (Banverket, 2010) & $\mathrm{T} 8$ \\
\hline & $\begin{array}{l}\text { Regularity per line, line class or area [no. or } \\
\% / \text { line, class or area] }\end{array}$ & - & T9 \\
\hline & Failures per item [no./item] & \multirow{4}{*}{$\begin{array}{l}\text { (Nyström and Ku- } \\
\text { mar, 2003, Granström } \\
\text { and Söderholm, 2005, } \\
\text { Granström, 2008, VTI, } \\
\text { 2011, Banverket, 2003) }\end{array}$} & T10 \\
\hline & $\begin{array}{l}\text { Failures per track-km, line, line class or area } \\
\text { [no./track-km, line, class or area] }\end{array}$ & & T11 \\
\hline & Delay per item [time/item] & & $\mathrm{T} 12$ \\
\hline & $\begin{array}{l}\text { Delay per line, line class or area [time/line, } \\
\text { class or area] }\end{array}$ & & $\mathrm{T} 13$ \\
\hline & $\begin{array}{l}\text { Temporary speed restrictions (TSRs) per line, } \\
\text { line class or area [no./line, class or area] }\end{array}$ & (BSL, 2009) & T14 \\
\hline \multirow{4}{*}{$\begin{array}{l}\text { Maintain- } \\
\text { ability }\end{array}$} & \multicolumn{3}{|l|}{ System level } \\
\hline & $\begin{array}{l}\text { Mean time to repair (MTTR) (or Mean time } \\
\text { to maintain (MTTM), or Maintainability) }\end{array}$ & $\begin{array}{l}\text { (INNOTRACK, 2009, } \\
\text { CEN, 1999) }\end{array}$ & $\mathrm{T} 15$ \\
\hline & \multicolumn{3}{|l|}{ Subsystem level } \\
\hline & $\begin{array}{l}\text { Mean time to repair (MTTR) per item (or } \\
\text { Maintainability) }\end{array}$ & $\begin{array}{l}\text { (Nyström and Kumar, } \\
\text { 2003, INNOTRACK, } \\
\text { 2009) }\end{array}$ & T16 \\
\hline
\end{tabular}


Table A.2: Continuation of technical railway infrastructure indicators.

\begin{tabular}{|c|c|c|c|}
\hline \multicolumn{4}{|c|}{ Technical indicators } \\
\hline Category & Indicators (Comments) [Unit] & Reference & \# \\
\hline \multirow{6}{*}{$\begin{array}{l}\text { Capacity } \\
\text { consumption }\end{array}$} & \multicolumn{3}{|l|}{ System level } \\
\hline & Traffic volume [train-km or tonne-km] & $\begin{array}{l}\text { (Åhrén and Ku- } \\
\text { mar, 2004, Banver- } \\
\text { ket, 2010) }\end{array}$ & T17 \\
\hline & \multicolumn{3}{|l|}{ Subsystem level } \\
\hline & $\begin{array}{l}\text { Traffic volume per line, line class or area [train-km } \\
\text { or tonne-km/line, class or area] }\end{array}$ & $\begin{array}{l}\text { (Åhrén and Ku- } \\
\text { mar, 2004, Banver- } \\
\text { ket, 2010) }\end{array}$ & T18 \\
\hline & $\begin{array}{l}\text { Capacity consumption (or Capacity utilisation) (24h } \\
\text { and } 2 \mathrm{~h} \text { ) [\%] }\end{array}$ & $\begin{array}{l}\text { (Åhrén and Ku- } \\
\text { mar, 2004, UIC, } \\
\text { 2004, Banverket, } \\
\text { 2010) }\end{array}$ & T19 \\
\hline & $\begin{array}{l}\text { Harmonised capacity consumption (double track } \\
\text { counted twice) [train-km/track-metre] }\end{array}$ & (Stenström, 2012a) & $\mathrm{T} 20$ \\
\hline \multirow{2}{*}{$\begin{array}{l}\text { Riding } \\
\text { comfort }\end{array}$} & \multicolumn{3}{|l|}{ Subsystem level } \\
\hline & Track quality index (TQI) (e.g. K-/Q-value) [index] & (BSL, 2009) & $\mathrm{T} 21$ \\
\hline \multirow{3}{*}{$\begin{array}{l}\text { OEE and } \\
\text { DEA }\end{array}$} & \multicolumn{3}{|l|}{ Subsystem level } \\
\hline & $\begin{array}{l}\text { Overall equipment effectiveness (OEE) per line, line } \\
\text { class or area [\%/line, class or area] }\end{array}$ & $\begin{array}{l}\text { (Åhrén and Parida, } \\
2009)\end{array}$ & $\mathrm{T} 22$ \\
\hline & Data envelopment analysis (DEA) [-] & $\begin{array}{l}\text { (George and Ran- } \\
\text { garaj, 2008, Mal- } \\
\text { hotra et al., 2009) }\end{array}$ & $\mathrm{T} 23$ \\
\hline \multirow{2}{*}{ Age } & \multicolumn{3}{|l|}{ Subsystem level } \\
\hline & $\begin{array}{l}\text { Mean age of assets (rail, S\&C, OCS, ballast, etc.) } \\
\text { [time] }\end{array}$ & $\begin{array}{l}\text { (Trafikverket, } \\
\text { 2011) }\end{array}$ & $\mathrm{T} 24$ \\
\hline
\end{tabular}


Table A.3: Organisational railway infrastructure indicators.

\begin{tabular}{|c|c|c|c|}
\hline \multicolumn{4}{|c|}{ Organisational indicators } \\
\hline Category & Indicators (Comments) [Unit] & Reference & \# \\
\hline \multirow{8}{*}{$\begin{array}{l}\text { Maintenance } \\
\text { management }\end{array}$} & \multicolumn{3}{|l|}{ System level } \\
\hline & $\begin{array}{l}\text { Preventive maintenance share (or Corrective } \\
\text { maintenance share) [\%] }\end{array}$ & (Unckel, 2010) & $\mathrm{O} 1$ \\
\hline & $\begin{array}{l}\text { Mean waiting time (MWT) (or Maintenance } \\
\text { supportability, or Organisational readiness, or } \\
\text { Reaction time, or Arrival time) [time] }\end{array}$ & $\begin{array}{l}\text { (INNOTRACK, } \\
2009 \text { ) }\end{array}$ & $\mathrm{O} 2$ \\
\hline & Maintenance backlog [no. or time] & (BSL, 2009) & O3 \\
\hline & Maintenance possession overrun [time or no.] & $\begin{array}{l}\text { (Olsson and Es- } \\
\text { pling, 2004) }\end{array}$ & $\mathrm{O} 4$ \\
\hline & \multicolumn{3}{|l|}{ Subsystem level } \\
\hline & $\begin{array}{l}\text { Preventive maintenance share (or Corrective } \\
\text { maintenance share) per line, line class, area } \\
\text { or item }[\% / \text { line, class, area or item }]\end{array}$ & \multirow[t]{2}{*}{ (Stenström, 2012a) } & O5 \\
\hline & $\begin{array}{l}\text { Mean waiting time (MWT) per line, line class, } \\
\text { area or item [time/line, class, area or Item] }\end{array}$ & & O6 \\
\hline \multirow{4}{*}{$\begin{array}{l}\text { Failure } \\
\text { reporting } \\
\text { process }\end{array}$} & \multicolumn{3}{|l|}{ System level } \\
\hline & $\begin{array}{l}\text { Faults in infrastructure with unknown cause } \\
\text { [no. or \%] }\end{array}$ & $\begin{array}{l}\text { (Stenström, } \\
2012 \mathrm{a}, \mathrm{b})\end{array}$ & O7 \\
\hline & \multicolumn{3}{|l|}{ Subsystem level } \\
\hline & $\begin{array}{l}\text { Faults in infrastructure with unknown cause } \\
\text { per line, line class, area or item [no. or \%/line, } \\
\text { class, area or item] }\end{array}$ & $\begin{array}{l}\text { (Stenström, } \\
2012 \mathrm{a}, \mathrm{b})\end{array}$ & O8 \\
\hline
\end{tabular}


Table A.4: Economic railway infrastructure indicators.

\begin{tabular}{|c|c|c|c|}
\hline \multicolumn{4}{|c|}{ Economic indicators } \\
\hline Category & Indicators (Comments) [Unit] & Reference & $\#$ \\
\hline \multirow{9}{*}{$\begin{array}{l}\text { Allocation of } \\
\text { cost }\end{array}$} & \multicolumn{3}{|l|}{ System level } \\
\hline & $\begin{array}{l}\text { Maintenance cost (incl. or excl. management } \\
\text { cost) [monetary] }\end{array}$ & $\begin{array}{l}\text { (BSL, 2009, Ban- } \\
\text { verket, 2010, } \\
\text { Trafikverket, 2011) }\end{array}$ & E1 \\
\hline & $\begin{array}{l}\text { Maintenance management cost (or Indirect } \\
\text { maintenance cost) [monetary] }\end{array}$ & $\begin{array}{l}\text { (Banverket, 2010, } \\
\text { Trafikverket, 2011) }\end{array}$ & E2 \\
\hline & $\begin{array}{l}\text { Maintenance cost per train-km, track-km } \\
\text { or gross-tonne-km [monetary/train-km, track- } \\
\mathrm{km} \text { or gross-tonne-km] }\end{array}$ & $\begin{array}{l}\text { (BSL, 2009, Ban- } \\
\text { verket, 2010, Wire- } \\
\text { man, 2003, UIC - } \\
\text { LICB, 2008) }\end{array}$ & E3 \\
\hline & Maintenance contractor cost [monetary] & $\begin{array}{l}\text { (Trafikverket, } \\
\text { 2011) }\end{array}$ & E4 \\
\hline & Corrective maintenance cost [monetary] & \multirow[t]{2}{*}{ (Stenström, 2012a) } & E5 \\
\hline & Preventive maintenance cost [monetary] & & E6 \\
\hline & \multicolumn{3}{|l|}{ Subsystem level } \\
\hline & $\begin{array}{l}\text { Maintenance cost per line, line class, area or } \\
\text { per item [monetary/line, class, area or item] }\end{array}$ & $\begin{array}{l}\text { (REMAIN, 1998, } \\
\text { Nissen, 2009a,b) }\end{array}$ & E7 \\
\hline
\end{tabular}


Table A.5: HSE (health, safety and environment) railway infrastructure indicators.

\begin{tabular}{|c|c|c|c|}
\hline \multicolumn{4}{|c|}{ HSE indicators } \\
\hline Category & Indicators (Comments) [Unit] & Reference & \# \\
\hline \multirow{3}{*}{ Health } & $\begin{array}{l}\text { Maintenance personnel absenteeism [time or } \\
\text { no.] }\end{array}$ & \multirow{3}{*}{ General } & H1 \\
\hline & Maintenance employee turnover [no.] & & $\mathrm{H} 2$ \\
\hline & Maintenance employee talks [no.] & & H3 \\
\hline \multirow{6}{*}{$\begin{array}{l}\text { Safety - } \\
\text { General }\end{array}$} & Urgent and one-week inspection remarks [no.] & \multirow{2}{*}{$\begin{array}{l}\text { (Stenström, } \\
\text { 2012a) }\end{array}$} & $\mathrm{H} 4$ \\
\hline & Harmonised inspection remarks & & H5 \\
\hline & $\begin{array}{l}\text { Deaths and injuries (or Casualties and acci- } \\
\text { dents) [no.] }\end{array}$ & $\begin{array}{l}\text { (BSL, 2009, } \\
\text { Trafikverket, 2011, } \\
\text { Holmgren, 2005) }\end{array}$ & $\mathrm{H} 6$ \\
\hline & Accidents at level crossings [no.] & $\begin{array}{l}\text { (Åhrén and Ku- } \\
\text { mar, 2004, BSL, } \\
\text { 2009) }\end{array}$ & $\mathrm{H} 7$ \\
\hline & Accidents involving railway vehicles [no.] & $\begin{array}{l}\text { (Åhrén and Ku- } \\
\text { mar, 2004) }\end{array}$ & $\mathrm{H} 8$ \\
\hline & $\begin{array}{l}\text { Incidents (or Mishaps, or Potential injuries) } \\
\text { [no.] }\end{array}$ & $\begin{array}{l}\text { (Trafikverket, } \\
\text { 2011) }\end{array}$ & H9 \\
\hline \multirow{4}{*}{$\begin{array}{l}\text { Safety - } \\
\text { Maintenance }\end{array}$} & $\begin{array}{l}\text { Maint. accidents and incidents (occurred and } \\
\text { potential) [no.] }\end{array}$ & \multirow[t]{2}{*}{ (Holmgren, 2005) } & H10 \\
\hline & $\begin{array}{l}\text { Failure accidents and incidents (occurred and } \\
\text { potential) [no.] }\end{array}$ & & H11 \\
\hline & Derailments [no.] & $\begin{array}{l}\text { (BSL, 2009, } \\
\text { Trafikverket, 2011, } \\
\text { Famurewa et al., } \\
\text { 2011) }\end{array}$ & $\mathrm{H} 12$ \\
\hline & Bucklings (or Sun kinks) [no.] & (BSL, 2009) & H13 \\
\hline \multirow{4}{*}{ Environment } & $\begin{array}{l}\text { Environmental accidents and incidents due to } \\
\text { failure [no.] }\end{array}$ & General & H14 \\
\hline & Energy consumption per area [J/area] & \multirow{3}{*}{$\begin{array}{l}\text { (Åhrén and } \\
\text { Kumar, 2004) }\end{array}$} & H15 \\
\hline & Use of environmental hazardous materials [-] & & H16 \\
\hline & Use of non-renewable materials [-] & & H17 \\
\hline
\end{tabular}


Table A.6: Condition monitoring of railway infrastructure and data extracted.

\begin{tabular}{|c|c|c|c|}
\hline Features & Method & $\begin{array}{l}\text { Parameters (component } \\
\text { level) }\end{array}$ & PIs (Subsystem level) \\
\hline \multicolumn{4}{|c|}{ Substructure - Embankment } \\
\hline $\begin{array}{l}\text { Ballast } \\
\text { composition }\end{array}$ & $\begin{array}{l}\text { Ground pene- } \\
\text { trating radar } \\
\text { (automatic) }\end{array}$ & $\begin{array}{l}\text { Ballast composition (layered } \\
\text { structure) }\end{array}$ & - \\
\hline \multirow{2}{*}{$\begin{array}{l}\text { Track stiff- } \\
\text { ness (related } \\
\text { to bearing } \\
\text { capacity) }\end{array}$} & $\begin{array}{l}\text { Hydraulic load- } \\
\text { ing (automatic } \\
\text { with stops) }\end{array}$ & $\begin{array}{l}\text { Track deflection/stiffness/ } \\
\text { strength }\end{array}$ & \multirow[t]{2}{*}{$\begin{array}{l}\text { Deduced: Stiffness loss } \\
\text { inspection remarks [no. } \\
\text { or no./length] }\end{array}$} \\
\hline & $\begin{array}{l}\text { Deflectographs } \\
\text { (continuous) }\end{array}$ & $\begin{array}{l}\text { Track deflection/stiffness/ } \\
\text { strength, Deflection speed }\end{array}$ & \\
\hline \multicolumn{4}{|c|}{ Substructure - Track geometry } \\
\hline \multirow[t]{2}{*}{ Geometry } & $\begin{array}{l}\text { Contact axles, } \\
\text { Optical sys., } \\
\text { Gyroscope sys., } \\
\text { Intertial sys. }\end{array}$ & $\begin{array}{l}\text { Gauge, Cross level, Cant, } \\
\text { Long. level, Twist, Geom- } \\
\text { etry of rails, Alignment, } \\
\text { Wheel-rail contact profile }\end{array}$ & $\begin{array}{l}\text { TQI (Track quality } \\
\text { index), based on std. } \\
\text { dev., commonly for each } \\
200 \mathrm{~m} \text {. } \\
\text { Deduced: Track geometry } \\
\text { inspection remarks [no. } \\
\text { or no./km] }\end{array}$ \\
\hline & $\begin{array}{l}\text { Failure report- } \\
\text { ing }\end{array}$ & Bucklings (or Sun kinks) & Bucklings [no.] \\
\hline \multicolumn{4}{|c|}{ Substructure - Track surroundings } \\
\hline $\begin{array}{l}\text { Clearance } \\
\text { and signal } \\
\text { visibility }\end{array}$ & Video system & $\begin{array}{l}\text { Vegetation clearance, Signal } \\
\text { visibility }\end{array}$ & $\begin{array}{l}\text { Track surroundings in- } \\
\text { spection remarks [no. or } \\
\text { no. } / \mathrm{km} \text { ] }\end{array}$ \\
\hline \multicolumn{4}{|c|}{ Superstructure - Rail } \\
\hline \multirow[t]{3}{*}{ Integrity } & $\begin{array}{l}\text { Continuous } \\
\text { monitoring } \\
\text { using sensors }\end{array}$ & $\begin{array}{l}\text { Temperature, Stress (longi- } \\
\text { tudinal) }\end{array}$ & $\begin{array}{l}\text { Deduced: Potential } \\
\text { buckling hazards [no. } \\
\text { or no./km], Poten- } \\
\text { tial rail breaks [no. or } \\
\text { no./km], Bucklings [no. } \\
\text { or no. } / \mathrm{km} \text { ], Rail breaks } \\
\text { [no. or no./km] }\end{array}$ \\
\hline & $\begin{array}{l}\text { Ultrasonic } \\
\text { inspection }\end{array}$ & $\begin{array}{l}\text { Discontinuities in central } \\
\text { part of head, web, foot and } \\
\text { running side }\end{array}$ & \multirow[t]{2}{*}{$\begin{array}{l}\text { Deduced: Ultrasonic and } \\
\text { eddy current inspection } \\
\text { remarks [no. or no. } / \mathrm{km} \text { ] }\end{array}$} \\
\hline & $\begin{array}{l}\text { Eddy current } \\
\text { inspection }\end{array}$ & $\begin{array}{l}\text { Discontinuities in the run- } \\
\text { ning surface }\end{array}$ & \\
\hline \multirow[t]{2}{*}{$\begin{array}{l}\text { Rail profile, } \\
\text { Rail surface, } \\
\text { Fasteners }\end{array}$} & $\begin{array}{l}\text { Optical profile } \\
\text { and surface } \\
\text { sys., LVDT } \\
\text { corrugation } \\
\text { sys., Axle box } \\
\text { accelerometers }\end{array}$ & $\begin{array}{l}\text { Profile, Gauge wear, Run- } \\
\text { ning surface wear, Rail } \\
\text { inclination, Rail type, Corru- } \\
\text { gation (amp. and } \lambda \text { ) }\end{array}$ & \multirow[t]{2}{*}{$\begin{array}{l}\text { Deduced: Inspection re- } \\
\text { marks requiring grinding, } \\
\text { rail replacement or com- } \\
\text { ponent replacement [no. } \\
\text { or no./km], Rail breaks } \\
\text { [No.] }\end{array}$} \\
\hline & Video system & $\begin{array}{l}\text { Rail breaks, Rail joints, } \\
\text { Burns/patches, Corrugation, } \\
\text { Fastenings }\end{array}$ & \\
\hline
\end{tabular}


Table A.7: Continuation of condition monitoring of railway infrastructure and data extracted.

\begin{tabular}{|c|c|c|c|}
\hline Features & Method & $\begin{array}{l}\text { Parameters (component } \\
\text { level) }\end{array}$ & PIs (Subsystem level) \\
\hline \multicolumn{4}{|c|}{ Superstructure - Switches and crossings (S\&C) } \\
\hline \multirow{6}{*}{$\begin{array}{l}\text { Geometry } \\
\text { and integrity }\end{array}$} & Geometry car & Track deflection at S\&Cs & $\begin{array}{l}\text { Deduced: S\&C deflection } \\
\text { inspection remarks [No. } \\
\text { or No./S\&C] }\end{array}$ \\
\hline & \multirow[t]{3}{*}{$\begin{array}{l}\text { Continuous } \\
\text { monitoring } \\
\text { using } \\
\text { sensors }\end{array}$} & $\begin{array}{l}\text { Contact area between blade } \\
\text { and rail, Switch flangeway } \\
\text { (open distance), Operational } \\
\text { force, Power and current } \\
\text { usage, Residual stress (re- } \\
\text { taining force), Detector rods } \\
\text { pos. }\end{array}$ & $\begin{array}{l}\text { Deduced: Malfunctions } \\
\text { per switch type [No. or } \\
\text { \%] (in open, in closed, } \\
\text { residual stress, detector } \\
\text { rods, power or current } \\
\text { consumption) }\end{array}$ \\
\hline & & Impacts on frog (wear) & $\begin{array}{l}\text { Deduced: Axis passing } \\
\text { [No.] }\end{array}$ \\
\hline & & $\begin{array}{l}\text { Rail temp, Stress (longitudi- } \\
\text { nal) }\end{array}$ & \\
\hline & $\begin{array}{l}\text { Mechatronic } \\
\text { system }\end{array}$ & $\begin{array}{l}\text { Gauge, Switch blades groove } \\
\text { width, Cross level, Twist }\end{array}$ & Switch total deviation \\
\hline & $\begin{array}{l}\text { Ultrasonic } \\
\text { Testing }\end{array}$ & $\begin{array}{l}\text { Discontinuities at critical } \\
\text { spots }\end{array}$ & $\begin{array}{l}\text { Deduced: Ultrasonic } \\
\text { testing remarks [No. or } \\
\text { No./switches] }\end{array}$ \\
\hline \multicolumn{4}{|c|}{ Superstructure - Overhead contact system (OCS) } \\
\hline \multirow[t]{2}{*}{$\begin{array}{l}\text { Position and } \\
\text { Condition }\end{array}$} & $\begin{array}{l}\text { Optical system } \\
\text { (laser) }\end{array}$ & $\begin{array}{l}\text { Vertical and lateral (stagger) } \\
\text { position of contact wire, } \\
\text { Contact wire thickness, } \\
\text { Abrasion patches at contact } \\
\text { wire }\end{array}$ & \multirow[t]{2}{*}{$\begin{array}{l}\text { Deduced: Inspection } \\
\text { remarks requiring } \\
\text { adjustment or } \\
\text { replacements of OCS } \\
\text { components [No. or } \\
\text { No. } / \mathrm{km} \text { ] }\end{array}$} \\
\hline & Video system & $\begin{array}{l}\text { Condition of catenary wire, } \\
\text { droppers, clamps and con- } \\
\text { tact wire }\end{array}$ & \\
\hline
\end{tabular}

